\title{
PUMPED-STORAGE HYDROPOWER PLANTS AS ENABLERS FOR TRANSITION TO CIRCULAR ECONOMY IN ENERGY SECTOR: A CASE OF LATVIA
}

\author{
J. Zvirgzdins ${ }^{1 *}$, O. Linkevics² \\ ${ }^{1}$ Institute of Civil Engineering and Real Estate Economics, \\ Riga Technical University, \\ 6 Kalnciema Str., Riga, LV-1048, LATVIA \\ ${ }^{2}$ Institute of Power Engineering, Department of Power System \\ Control and Automation, Riga Technical University, \\ 12/1 Azenes Str., Riga, LV-1048, LATVIA \\ *e-mail: Janis.Zvirgzdins_1@ @rtu.Iv
}

Nowadays the planet is facing emerging global issues related to climate change, pollution, deforestation, desertification and the number of challenges is expected to grow as the global population is forecasted to reach 10 billion margin by 2050. A concept of circular economy can have a positive contribution to the current development trajectories. In order to implement it, preferably all the energy should be produced by using renewable energy sources, but there has always been a challenge for storage of renewable energy. Therefore, considering technical and economical parameters, construction options for a pumped storage hydropower plant in Latvia have been evaluated using the desk research methodology. Results have shown that Daugavpils PSHP is the most attractive project from the technological point of view, but it requires the greatest amount of investment and construction of Daugavpils HPP. At present all the construction options for PSHP in Latvia are economically disadvantageous and would not be viable without co-financing from European or national funds. Considering both technical and economical parameters, the authors emphasise Plavinas PSHP construction option.

Keywords: circular economy, electricity price, pumped storage hydropower plant, renewable energy 
In the 21st century, the role of environment and ecology is becoming increasingly important. Climate change, water and air pollution, deforestation, desertification are problems that are directly and indirectly influencing the standard of living for a huge part of population worldwide [1]. The global population is growing and the demand for such basic needs as food, housing and transportation is also increasing. For a long time, our economy has been linear, which is characterised by a 'take-makedispose' approach. In the long-term, it has converted the planet Earth into a landfill, as $60 \%$ of global waste is disposed. Current development trajectories raise serious questions about the sustainability of the planet Earth and require urgent action.

A promising concept in the scientific and governmental environment on which a more sustainable world can be built is a circular economy. In 1966, American economist Kenneth Ewart Boulding drew an analogy regarding rather circular than linear flow of material resources. It reflected transformation from 'cowboy economy' characterised by endless resources and the ability to abandon problems to 'spaceship economy', where limited resources had to be reused and recycled as a precondition to sustainable life-support systems [2]. The concept aims at increasing the resource efficiency, closing resource and material loops, designing out waste, sharing products, extending the life time of products and services, decreasing the demand for resources and products and sustainable consumption. Stable national economy, favourable political environment, competitive business, intensive cooperation between the academy and business, secure social environment and other factors are governed by the regulatory framework implemented by the state, which enables the government to promote, restrict and hinder the development of the national economy [3]. Additionally, the research and development (R\&D) level and the development of innovations are crucial factors for any economy that follows global trends [4]. Great emphasis regarding the development of economy is placed on the energy sector. Within the concept of circular economy, preferably all the energy should be produced from renewable energy sources. It is in accordance with the aims of the Blue Growth concept developed by the European Commission [5]. Kurzeme Region contains the greatest potential for renewable energy resource development as it has more than $350 \mathrm{~km}$ long Baltic Sea coast [6]. However, there are great challenges related to the storage of renewable energy. Nowadays there are such common storage technologies as electric batteries [16], electric flywheels, compressed air energy storage, superconductors, superconducting magnetic energy storage systems, as well as pumped-storage hydropower plants (PSHPs). New ways of electric energy storage, such as using electric batteries of electric vehicles are considered [17]. As long as the PSHPs are linked to $99 \%$ of the globally installed capacity of energy storage facilities, they have the greatest influence on the energy sector and the greatest potential in providing benefits [7; 18].

If major trends in the era of energy transition, which determine the pathways for technological development, are being discussed, then decarbonisation, increased share of intermittent renewables and changing role of conventional fossil generation should be noted. As a result, there is an urgent need for efficient and competitive storage tech- 
nologies. Solutions for these challenges are developed via sector coupling and powerto-X. Sector coupling refers to the idea of interconnecting the energy consuming sectors - buildings (heating and cooling), transport, and industry - with the power producing sector via increased electrification, e-hydrogen (power-to-gas) and e-fuels (power-to-fuel) [8]. In the power-to-X equation, $\mathrm{X}$ can refer to a number of things: power-to-ammonia, power-to-chemicals, power-to-heat, power-to-hydrogen, powerto-liquid, power-to-fuel and power-to-gas, etc. [9]. At this point, the greatest emphasis is placed on power-to-fuel and power-to-gas to decarbonise global economy. This is a great example of circular economy.

Developing the energy sector, especially its core industry electricity, new tasks are emerging, including integration of renewable energy resources into power systems. Performing these tasks ensures more efficient and stable electricity generation, transmission and distribution. A significant part of these tasks can be carried out by pumpedstorage hydropower plants (PSHPs), thus removing load from production facilities.

The most important renewable energy resources for electricity supply are solar and wind energy, as they have already proven to be the most appropriate among other renewable energy sources. Surplus power from wind farms and solar power plants could be used to pump water from the lower reservoir to the upper reservoir, so that during periods of power shortage PSHP could operate in turbine mode and generate electrical power covering the demand. However, these two types of renewable energy in terms of their unpredictable and unstable nature create challenges for power systems.

Electricity demand is uneven every 24 hours. The greatest electricity demand is in daylight and in the evening. Night is the time when most businesses do not work and electricity demand is not so great. Based on economic demand and supply law, it follows that electricity is relatively more expensive during the daytime compared to the night hours. The difference in the electricity price can be used by PSHPs.

PSHPs consume relatively cheap electricity during the night to pump water from the lower reservoir to the upper reservoir. However, during the day when electricity is relatively expensive, water flows from upper reservoir to lower reservoir through the turbine and produces electricity that can be delivered to consumers. In this way, PSHPs equalize daily load schedule and, based on electricity price difference at different times of the day, obtain economic benefits. Additionally, PSHPs play a major role in power regulation of nuclear power plants. Power generation in nuclear power plants cannot be easily stopped. Power capacity of nuclear power plants could not be reduced easily even in night time when electric demand of power system is lower. Excess power could be used to drive pumps of PSHPs. During the day when demand is growing, stored water in an upper pool of PSHP could be used to produce electricity in turbine mode. Therefore, the PSHP is used to provide the base mode for nuclear power plants. For example, Kruonis PSHP, which is closest to Latvia, was built as support for the Ignalina nuclear power plant.

Use of PSHPs for various applications in many cases could be more economically viable than if the same tasks were performed by conventional power plants. The use of storage technologies would also reduce the environmental impact of power plants, which is currently one of the priorities in a large part of the world.

The main goal of the paper is to evaluate possible construction of a pumped-storage hydropower plant in Latvia and its contribution to Latvia. 
The construction of PSHPs requires large investment, and the payback period is approximately 30 years. Considering these factors and the fact that economic growth of Latvia is limited, implementation of all projects would be impossible, so the authors of the article using the desk research methodology will compare the options of
PSHPs and recommend one of the previously investigated projects (Daugavpils, Plavinas or Riga) that would be most beneficial to implement. Analysis of technological indicators will be carried out based on the developed projects. Economic indicators will be analysed based on the Nord Pool electricity prices.

\section{PUMPED-STORAGE HYDROPOWER PLANTS}

In the beginning, the authors would like to provide a review of the advantages and disadvantages of PSHPs (see Table 1). Advantages of PSHPs are long service life, low losses of energy storage, relatively high efficiency (70-85\%) comparing to other energy storage technologies and the ability to install very large storage capacity. The main efficiency losses are related to gravity force, which needs to be overcome when pumping water from lower reservoir to upper reservoir. On the other hand, implementing a PSHP project takes long planning and construction time, specific geographical conditions that may be limited according to environmental constraints. Large amount of initial investment and long payback period are PSHP development hindering factors as well.

Table 1. Advantages and Disadvantages of Pumped-Storage Hydropower Plants (developed by the authors)

\begin{tabular}{|c|c|}
\hline Advantages & Disadvantages \\
\hline Long service life & Long planning and construction time \\
\hline Low losses & $\begin{array}{c}\text { Specific geographical conditions for upper reservoir } \\
\text { and lower reservoir }\end{array}$ \\
\hline Relatively high efficiency & Low power and energy density \\
\hline Ability to install very large storage capacity & Large amount of initial investment \\
\hline
\end{tabular}

In order to exploit the benefits of advantages of PSHPs, it is important to under- stand if electricity prices can ensure profitability of PSHPs.

\section{WIND POWER GENERATION AND ELECTRICITY PRICE ANALYSIS}

Produced energy by solar panels and wind generators, which are installed in the territory of Latvia, is directly dependent on the number of sunny and windy days during the year. It is hard to forecast the amount of energy produced by these technologies, especially with the increasing influence of climate change.

Figure 1 shows the estimated wind power and actual wind power from 8 July 2019 to 14 July 2019, which confirms the unpredictability (average relative error $50.6 \%$; maximum relative error $-200 \%$ ) of this renewable energy source and proves 
the need of the energy storage system. It would be useful to use PSHPs, and the Daugava River with its hydroelectric power plants has good potential for the development of PSHP in Latvia.

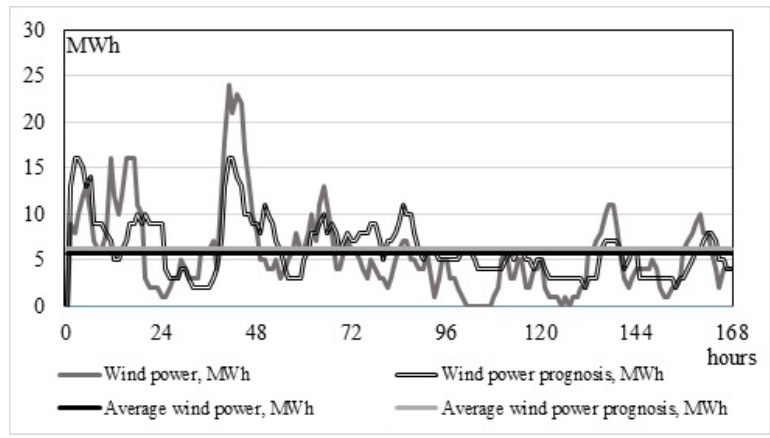

Fig. 1. Wind power and wind power forecast from 8 July 2019 to 14 July 2019 (created by the authors from [10] and [11]).

Based on average electricity prices in Latvia in different times around the clock, the construction of PSHP in Latvia is supportable. Taking into account that average efficiency of PSHP is $77.5 \%$, the price difference should be at least $22.5 \%$ to make the use of PSHP profitable. This price difference will be sufficient to cover operational expenses of PSHP. In reality the price variation shall be even higher to cover investment costs. Figure 2 illustrates that the lowest average price in 2018 has been between 3 am and 4 am (37.39 EUR/MWh), but the highest average price has been observed between $9 \mathrm{am}$ and $10 \mathrm{am}$ (60.07 EUR/ MWh). The $37.8 \%$ difference between these prices can be used by PHSPs. Considering the fact that PSHPs would need more than 1 hour in turbine and pump mode, the authors have calculated the price difference between average price at night (from $11 \mathrm{pm}$ to $6 \mathrm{am})-39.07 \mathrm{EUR} / \mathrm{MWh}$ and average price during the day time (from 7 am to 9 pm) - 56.09 EUR/MWh. Calculations have shown the price difference of $30.3 \%$.

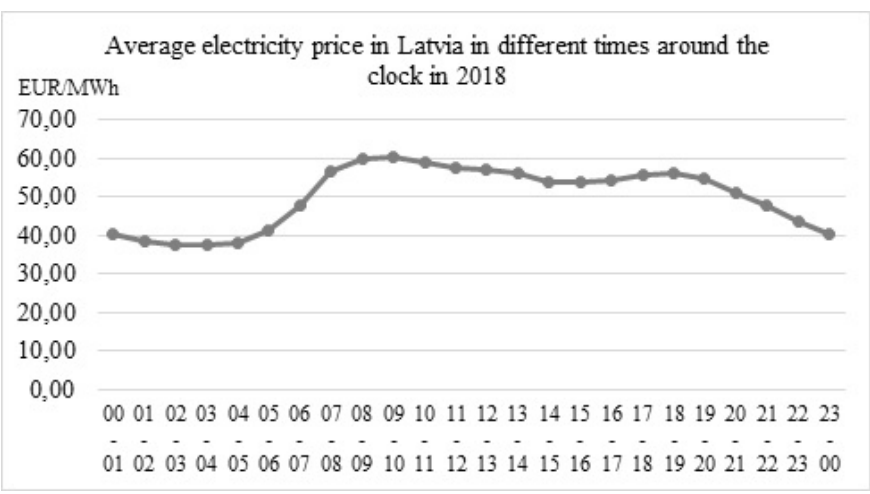

Fig. 2. Average electricity price in Latvia in different times around the clock in 2018 (created by the authors from [12]).

Considering electricity prices and the expected development of wind and solar energy systems, the authors can state that during periods of high wind power and solar power, electricity prices could be very low, but during cloudy and windless days 
electricity prices could be high.

Taking into account the unpredictability of wind power and average electricity prices in Latvia, further research regarding construction options of PSHP in Latvia has been carried out.

\section{RESULTS AND DISCUSSION}

The authors have compared 3 PSHP construction options in Latvia - Daugavpils PSHP, Pump station combined with planned

\section{1) Daugavpils PSHP}

In 1986, the proposal for Daugavpils PSHP was made by project institute 'Hydroproject'. The idea for the construction of the PSHP was related to the Daugavpils hydro HPP construction, which was already underway. It allowed using a construction base located near Daugavpils, equipment and personnel after commissioning of Daugavpils HPP in 1990. These conditions allowed starting construction close to HPP. The construction location (see Fig. 3) was picked $8 \mathrm{~km}$ from Daugavpils HPP, which provided conditions to use the reservoir of Daugavpils HPP as lower reservoir of Daugavpils PSHP. The two following Daugavpils PSHP options were presented: 1) installed power of $1574 \mathrm{MW}$ and 10 Francis (reverse) hydro units; and 2) installed power of $1260 \mathrm{MW}$ and 8 Francis hydro units [13].

However, the authors offer construction options with 5 or 4 hydro units, which emergency spillways of Plavinas HPP (Hydroelectric Power Plant) (Plavinas PSHP) and Pump station near Riga HPP (Riga PSHP).

are technologically and economically more feasible under current conditions of the Latvian energy sector.

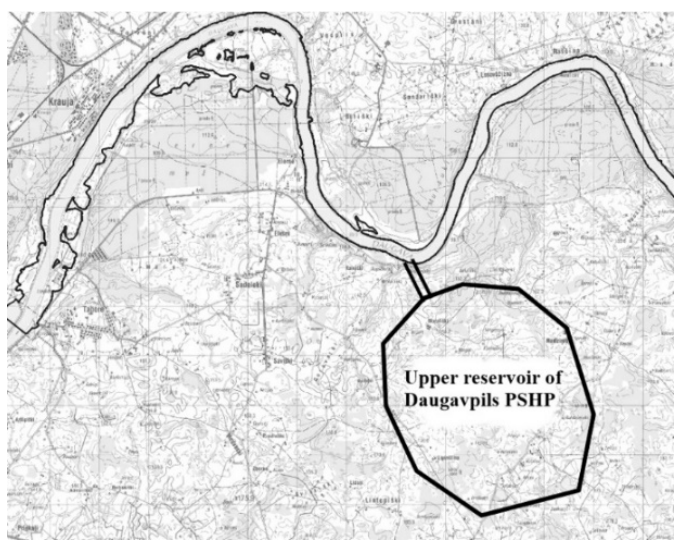

Fig. 3. Planned location of Daugavpils PSHP.

It should be stated that the planned location of Daugavpils PSHP is within the territory of Nature Park "Daugavas loki", where the construction and other economic activities are limited.

\section{2) Pump Station combined with planned emergency spillways of Plavinas HPP (Plavinas PSHP)}

Plavinas PSHP is designed to store potential energy by pumping water from Kegums HPP reservoir (lower reservoir) to Plavinas HPP (upper reservoir). Plavinas PSHP is based on a pump station built into emergency spillways of Plavinas hydroelectric power plant [14]. The necessity of emergency spillways at Plavinas HPP was emphasised already in 1994 and its main objective would be to increase the dam safety level of Plavinas HPP. Probable Maximum Flood (PMF) flow in the dam of Plavinas HPP with the probability of 1 in every 10000 years is $12600 \mathrm{~m}^{3} / \mathrm{s}$. Existing spillways of Plavinas HPP dam has the throughput of $8640 \mathrm{~m}^{3} / \mathrm{s}$ at the highest 
permissible level in the reservoir $(73.3 \mathrm{~m}$ above sea level). In this case, there is a 3960 $\mathrm{m}^{3} / \mathrm{s}$ shortage in the throughput of the Plavinas HPP dam that justifies the construction necessity of emergency spillways. It could also be used if smaller floods need to be drained and it can operate independently.

Figure 4 illustrates optimal deployment of the emergency spillways of Plavinas HPP.

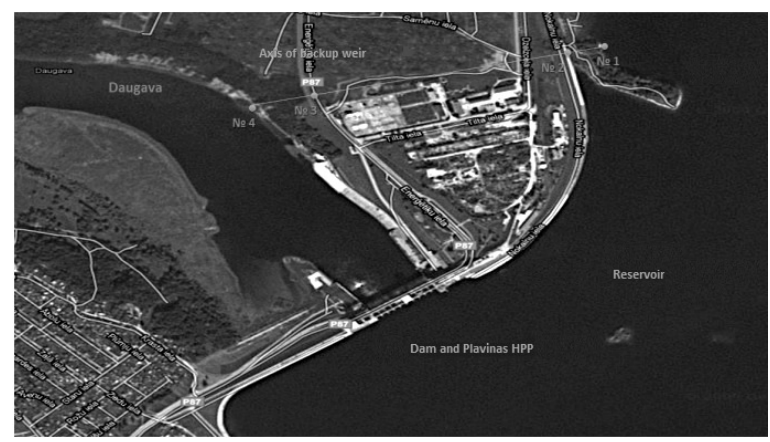

Fig. 4. Optimal deployment of the emergency spillways of Plavinas HPP [14].

The main environmental impacts from Plavinas PSHP project implementation are linked to migration disturbance of living organisms to certain areas and creation of additional erosion in the Daugava. Overall, no significant negative environmental impacts were identified that could prohibit the planned construction [14].

\section{3) Pump Station near Riga HPP (Riga PSHP)}

According to the Latvenergo Riga PSHP assessment in 2012, the construction of a separate pumping station is considered to be the most efficient option. Hydro units of Riga hydroelectric power plant would be used to generate electricity [15].

Figure 5 shows the potential locations of the pumping station -1) the left side of Riga HPP reservoir, near the Dry Daugava (Pumping station 1);2) near the dam of Riga HPP, right coast of the Daugava (Pumping station 2).

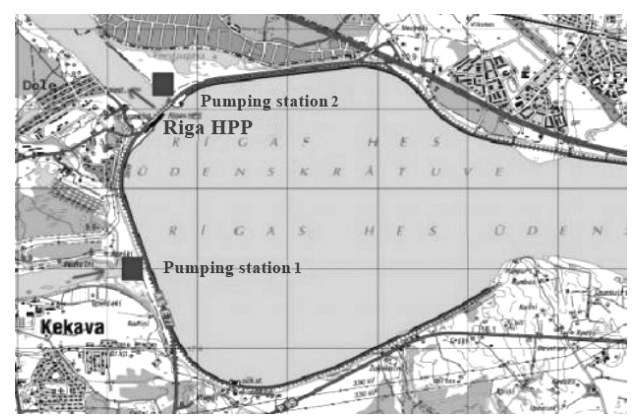

Fig. 5. Potential location of Riga PSHP pump stations [15].
In case of constructing pumping station 1 on the left coast of the Daugava, water pumping would be done for $8 \mathrm{~km}$ via Dry Daugava, which is the left tributary of the Daugava, separated from the water course by Dole Island. This pump station construction option would require $8 \mathrm{~km}$ deepening of the water course, which would significantly increase the required investment of the Riga PSHP project. However, if the pumping station were built on the right coast of the Daugava (Pumping station 2), the amount of water available for pumping would be over 20 million $\mathrm{m}^{3}$, which could provide a pumping station with a flow rate of $160 \mathrm{~m}^{3} / \mathrm{s}$ for more than 24 hours, allowing to conclude that the flow of water would compensate the pumping of water [15].

The potential Riga PSHP pump station deployment is close to the territory of Nature Park "Doles sala", where the construction and other economic activities are limited. Construction of pump station 
could create adverse effects on coastal erosion, biodiversity, geological processes and

\section{4) Overview}

The authors have compared technical and economic parameters of 3 PSHP construction options in Latvia - Daugavpils PSHP, Pump station combined with planned emergency spillways of Plavinas HPP and Pump station near Riga HPP.

Table 2 reflects technical parameters of Daugavpils, Plavinas and Riga PSHP construction options. The greatest installed power in the pump (826 MW) and turbine (630 MW) mode is linked to the Daugavpils PSHP construction option, which can be justified by the fact that water head $(73 \mathrm{~m})$ in this option is the greatest as well. Plavinas PSHP installed power in turbine mode is $8 \mathrm{MW}$ higher than the installed power safety of current hydrotechnics [15].

of Riga PSHP in turbine mode. Water consumption in turbine mode is lower than water consumption in pump mode for all construction options due to gravitational force that must be overcome when pumping water. In the option of Daugavpils PSHP, it is planned to build a pumped-storage hydropower plant with an upper reservoir and 4 reverse hydro units, but in the case of Plavinas and Riga PSHP construction options it is planned to build a pumping station with 2 and 5-7 pumps, respectively. The lowest specific water consumption is in the case of Daugavpils PSHP. It is explaned by the highest water head.

Table 2. Comparison of Technical Parameters of PSHP

Construction Options in Latvia (developed by the authors)

\begin{tabular}{|c|c|c|c|}
\hline & Daugavpils PSHP & $\begin{array}{c}\text { Pump station combined } \\
\text { with planned emergency } \\
\text { spillways of Plavinas HPP }\end{array}$ & $\begin{array}{c}\text { Pump station near } \\
\text { Riga HPP }\end{array}$ \\
\hline $\begin{array}{l}\text { Installed power in pump } \\
\text { mode (MW) }\end{array}$ & 826 & 36.2 & 28.2 \\
\hline $\begin{array}{l}\text { Installed power in turbine } \\
\text { mode (MW) }\end{array}$ & 630 & 90 & 64.7 \\
\hline $\begin{array}{l}\text { Number of hydro units/ } \\
\text { pumps }\end{array}$ & 4 hydro units & 2 pumps & 5-7 pumps \\
\hline Water head (m) & 73 & 35 & 14 \\
\hline $\begin{array}{l}\text { Efficient water volume } \\
\left(\text { million } \mathrm{m}^{3}\right)\end{array}$ & 20.76 & 25.23 & 41 \\
\hline $\begin{array}{l}\text { Water consumption in } \\
\text { pump mode }\left(\mathrm{m}^{3} / \mathrm{s}\right)\end{array}$ & 960 & 80 & 159.3 \\
\hline $\begin{array}{l}\text { Water consumption in } \\
\text { turbine mode }\left(\mathrm{m}^{3} / \mathrm{s}\right)\end{array}$ & 968 & 262 & 478 \\
\hline $\begin{array}{l}\text { Specific water consump- } \\
\text { tion in pump mode }\left(\mathrm{m}^{3} /\right. \\
\left.\mathrm{MW}^{*} \mathrm{~s}\right)\end{array}$ & 1.16 & 2.21 & 5.65 \\
\hline $\begin{array}{l}\text { Specific water consump- } \\
\text { tion in turbine mode }\left(\mathrm{m}^{3} /\right. \\
\left.\mathrm{MW}^{*} \mathrm{~s}\right)\end{array}$ & 1.54 & 2.91 & 7.39 \\
\hline
\end{tabular}


Table 3 reflects economic indicators of PSHP construction options in Latvia. Daugavpils PSHP construction option has the largest consumed and produced amount of electricity, which also generates the highest profit, but the investment is more than 30 times greater than the planned investment for Plavinas PSHP, where only the construction of a pumping station is planned. The operating costs for the Daugavpils PSHP construction option are also the highest ones. If $85 \%$ of the investment were to be covered by co-financing from European or national funds, Daugavpils PSHP construction option would pay off in 27 years, Plavinas - in 26 years, but Riga - would not pay off even in 50 years. Electricity consumption and production volumes of different PSHP options were estimated based on simulation of PSHP hourly operating modes. For evaluation of annual revenue values Nord Pool electricity price variations were taken into account.

Table 3. Comparison of Economical Parameters of PSHP

Construction Options in Latvia (developed by the authors)

\begin{tabular}{|c|c|c|c|}
\hline Economic indicator & Daugavpils PSHP & $\begin{array}{c}\text { Pump station com- } \\
\text { bined with planned } \\
\text { emergency spillways } \\
\text { of Plavinas HPP }\end{array}$ & $\begin{array}{l}\text { Pump station near } \\
\text { Riga HPP }\end{array}$ \\
\hline $\begin{array}{l}\text { Consumed electricity in pump } \\
\text { mode (GWh) }\end{array}$ & 2205 & 107 & 69 \\
\hline $\begin{array}{l}\text { Produced electricity in turbine } \\
\text { mode (GWh) }\end{array}$ & 1695 & 85 & 52 \\
\hline $\begin{array}{l}\text { Annual electricity generation costs } \\
\text { (million EUR) }\end{array}$ & 74.471 & 3.665 & 2.310 \\
\hline Annual revenue (million EUR) & 87.014 & 4.343 & 2.679 \\
\hline Annual profit (million EUR) & 12.543 & 0.678 & 0.369 \\
\hline $\begin{array}{l}\text { Approximate volume of invest- } \\
\text { ment (million EUR) }\end{array}$ & 740.516 & 23.136 & 28.227 \\
\hline $\begin{array}{l}\text { Investment if } 85 \% \text { is financed by } \\
\text { the government or the European } \\
\text { Union (million EUR) }\end{array}$ & 111.077 & 3.47 & 4.23 \\
\hline Operating costs (million EUR) & 3.7 & 0.4 & 0.2 \\
\hline NPV (million EUR) & 14.16 & 0.493 & -1.203 \\
\hline IRR $(\%)$ & 9.1 & 9.2 & 5.5 \\
\hline $\begin{array}{l}\text { Payback period, if } 85 \% \text { of invest- } \\
\text { ment is subsidized (years) }\end{array}$ & 27 & 26 & $>50$ \\
\hline
\end{tabular}

The authors have carried out the comparison of advantages and disadvantages of PSHP construction options in Latvia (see Table 4). Advantages of Daugavpils PSHP construction option are the most appropriate water head of 73 metres and planned reverse aggregates, which are common all over world. However, the construction of
Daugavpils PSHP construction option can be carried out only if Daugavpils HPP is built before that. Additionally, $85 \%$ cofinancing from the Latvian government or the EU is required to ensure the payback period of 27 years. Implementation of pump station near Riga HPP (Riga PSHP) would require smaller investment volumes 
compared to Daugavpils PSHP, but there would be several disadvantages - the lowest water head of all 3 construction options, lack of global practices where PSHP is constructed as a pump station that is built next to the HPP, potential higher required invest- ment if a pump station is constructed near Dry Daugava and possible Riga HPP level restrictions related to the operation of Riga port. Taking into account projected energy prices, all three PSHP construction options are economically disadvantageous.

Table 4. Comparison of Advantages and Disadvantages of PSHP Construction Options in Latvia

\begin{tabular}{|c|c|c|}
\hline $\begin{array}{l}\text { Construction } \\
\text { option }\end{array}$ & Advantages & Disadvantages \\
\hline $\begin{array}{l}\text { Daugavpils } \\
\text { PSHP }\end{array}$ & $\begin{array}{l}\text { The most appropriate } \\
\text { water head for PSHP con- } \\
\text { struction in Latvia (73 m) } \\
\text { - Construction of PSHP } \\
\text { is planned with reverse } \\
\text { aggregates, which are } \\
\text { common all over world } \\
\text { The lowest specific water } \\
\text { consumption, which is } \\
\text { explained by the highest } \\
\text { water head }\end{array}$ & $\begin{array}{l}\text { To implement Daugavpils PSHP construction project, } \\
\text { there is a necessity to build Daugavpils HPP before that } \\
\text { - } 85 \% \text { of co-financing from Latvia and the EU is required } \\
\text { to ensure the payback period of } 27 \text { years } \\
\text { - Taking into account the estimated energy prices, } \\
\text { Daugavpils PSHP construction is economically disad- } \\
\text { vantageous without co-financing }\end{array}$ \\
\hline $\begin{array}{l}\text { Pump station } \\
\text { combined with } \\
\text { planned emer- } \\
\text { gency spillways } \\
\text { of Plavinas HPP }\end{array}$ & $\begin{array}{l}\text { - Smaller investment } \\
\text { volumes compared to } \\
\text { Daugavpils PSHP } \\
\text { - Water head is } 2 \text { times } \\
\text { greater compared to } \\
\text { Riga HPP } \\
\text { - Efficient use of emergency } \\
\text { spillways }\end{array}$ & $\begin{array}{l}\text { - To build a pump station combined with planned emer- } \\
\text { gency spillways of Plavinas HPP, there is a necessity to } \\
\text { build emergency spillways of Plavinas HPP } \\
\text { - There is a lack of global practices where PSHP is con- } \\
\text { structed as a pump station that is built next to the HPP } \\
\text { - Taking into account the estimated energy prices, Plavi- } \\
\text { nas PSHP construction is economically disadvantageous } \\
\text { without co-financing }\end{array}$ \\
\hline $\begin{array}{l}\text { Pump station } \\
\text { near Riga HPP }\end{array}$ & $\begin{array}{l}\text { Smaller investment } \\
\text { volumes compared to } \\
\text { Daugavpils PSHP }\end{array}$ & $\begin{array}{l}\text { - Lowest water head out of all } 3 \text { construction options } \\
\text { - There is a lack of global practices where PSHP is con- } \\
\text { structed as a pump station that is built next to the HPP } \\
\text { - Pump station construction option near Dry Daugava } \\
\text { would require } 8 \mathrm{~km} \text { deepening of the water course, } \\
\text { which would significantly increase the required invest- } \\
\text { ment } \\
\text { Possible Riga HPP level restrictions related to the opera- } \\
\text { tion of Riga port } \\
\text { - Taking into account the estimated energy prices, Riga } \\
\text { PSHP construction is economically disadvantageous } \\
\text { even with co-financing }\end{array}$ \\
\hline
\end{tabular}

Considering the advantages and disadvantages of PSHP construction options in
Latvia, the authors would recommend the construction of Plavinas PSHP. 
Having conducted the present research, the authors have come to the following conclusions:

1. Latvia currently does not have cheap base power sources that can be used for night-time pumping, so this power would have to be imported. In the future with growth of solar and wind capacity, this source of cheap electricity for water pumping will appear.

2. During peak hours, the existing Daugava HPP cascade could be used in Latvia. Therefore, the capacity of the Latvian PSHP should be offered in the Baltic market, competing with the Kruonis PSHP.

3. The need for Latvian PSHP in the future could be determined by the increasing capacity of wind and solar power plants.

4. None of the PSHP projects (Daugavpils PSHP, Pump station combined with planned emergency spillways of Plavinas HPP, Pump station near Riga HPP) is economically advantageous taking into account the current market situation. The EU or national co-financing of $85 \%$ is required for projects to be viable.

5. From the technical point of view, taking into account the most appropriate water head, the best option is the construction of a new Daugavpils PSHP. However, this construction option is feasible only in case if the Daugavpils HPP is built. Daugavpils PSHP construction option is the most expensive one (740.5 mil- lion EUR), but the PSHP would have the largest installed power (630 MW).

6. The construction of a pump station at the emergency spillways of Plavinas HPP is the best construction option from the economic point of view and the authors recommend this option as the most suitable one for construction of the Latvian PSHP. Plavinas PSHP construction option has the lowest amount of investment, average (among 3 construction options) water head, and it provides opportunity for efficient use of emergency spillways. However, this project could be implemented only if emergency spillways are constructed.

7. The construction of a pump station at Riga HPP could make operation of the Port of Riga more difficult and could cause ecological problems for the Dry Daugava. Water head of this construction option is also the smallest, which determines the largest amount of water that needs to be pumped in order to obtain the same generator power (compared to Daugavpils PSHP).

8. Even though the case of Latvia for construction of PSHP has proven to be economically disadvantageous, the construction of PSHP in other countries worldwide should be considered in order to create opportunities for integration of renewable energy sources into energy systems and promote transition to circular economy.

\section{REFERENCES}

1. Geipele, I., Plotka, K., Wirzhbitskis, Y., \& Zvirgzdinšs, J. (2018). The synergy in circular economy. Advances in Economics, Business and Management Research, China, Hohhot,
20-22 October 2018. (pp. 65-68). Atlantis Press. DOI: 10.2991/febm-18.2018.15

2. Boulding, K.E. (1966). The economics of the coming spaceship earth. In H. Jarrett (Ed.), 
Environmental Quality Issues in a Growing Economy, pp. 3-14.

3. Geipele, S., Pudzis, E., Uzulens, J., Geipele, I., \& Zeltins, N. (2018). The Development of Nanotechnologies and Advanced Materials Industry in Science and Entrepreneurship: Legal Indicators. A Case Study of Latvia (Part Four). Latvian Journal of Physics and Technical Sciences, 55 (4), 44-56. DOI: 10.2478/lpts-2018-0028

4. Geipele, S., Geipele, I., Kauskale, L., Zeltins, N., Staube, T., \& Pudzis, E. (2017). The Development of Nanotechnologies and Advanced Materials Industry in Science and Entrepreneurship: Scientific Indicators. A Case Study of Latvia (Part Three). Latvian Journal of Physics and Technical Sciences, 54 (5), 3-13. DOI: 10.1515/lpts-2017-0029

5. Pudzis, E., Ādlers, Ā., Puḳīte, I., Geipele, S., \& Zeltinš, N. (2018). Identification of Maritime Technology Development Mechanisms in the Context of Latvian Smart Specialisation and Blue Growth. Latvian Journal of Physics and Technical Sciences, 55 (4), 57-69. ISSN 0868-8257. DOI: 10.2478/lpts-2018-0029

6. Actina, G., Geipele, I., \& Zeltins, N. (2015). Planning and managing problems of energy and energy efficiency at regional and district level in Latvia: case study. In Industrial Engineering and Operations Management: Proceedings of the 5th International Conference on Industrial Engineering and Operations Management (IEOM). Dubai United Arab Emirates, 3-5 March 2015 (pp. 1482-1488). DOI: 10.1109/ IEOM.2015.7093843

7. Carnegie, R., Gotham, D., Nderitu, D., \& Preckel, P.V. (2013). Utility Scale Energy Storage Systems: Benefits, Applications and Technologies. State Utility Forecasting Group. Available at: https://www.purdue. edu/discoverypark/energy/assets/pdfs/ SUFG/publications/SUFG\%20Energy\%20 Storage\%20Report.pdf

8. Appun, K. (2018). Sector Coupling-Shaping an Integrated Renewable Energy System. Journalism for the Energy Transition. Available at: https://www.cleanenergywire. org/factsheets/sector-coupling-shapingintegrated-renewable-power-system
9. Cord, D.J. (2018). Power-to-X: A potential Sparker in the Energy Transition. Wärtsilä. Available at: https://www.wartsila.com/ twenty four7/innovation/power-to-x-apotential-sparker-in-the-energy-transition

10. Nord Pool Spot. (2019). Wind Power. Available at: https://www.nordpoolgroup. com/Market-data1/Power-system-data/ Production1/Wind-Power/

11. Nord Pool Spot. (2019). Wind Power Prognosis. Available at: https://www. nordpoolgroup.com/Market-data1/Powersystem-data/Production 1/Wind-PowerPrognosis/ALL/Hourly/?view=table

12. Nord Pool Spot. (2019). Historical Market Data. Available at: http://nordpoolspot.com/ historical-market-data/

13. Даугавпилсская ГАЭС Предложение, Проектно-изыскательский и научноисследовательский институт “Гидропроект" имени С. Я. Жука. (1986). [Daugavpilsskaya GAES Predlozhenie, Projektno-vziskateljnij i nauchnoissledovateljskij institute "Gidroproekt" imeni S.J. Zhuka], Москва.

14. Pḷavinuu HAES izvērtējums: Pḷavinu HES rezerves pārgāznē iebūvēta sūkṇu stacija (2015). Rīga: Latvenergo, 34 lpp.

15. Rīgas HAES novērtējums (2012). Rīga: Latvenergo, $46 \mathrm{lpp}$.

16. Petrichenko, L., Broka, Z., Sauhats, A., \& Bezrukovs, D. (2018). Cost-Benefit Analysis of Li-Ion Batteries in a Distribution Network. 15th International Conference on the European Energy Market (EEM) (pp. 1-5). IEEE. DOI: 10.1109/EEM.2018.8469782

17. Zima-Bockarjova, M., Sauhats, A., Petrichenko, L., \& Petrichenko, R. (2020). Charging and Discharging Scheduling for Electrical Vehicles Using a Shapley-Value Approach. Energies, 13 (5), 1160. DOI: 10.3390/en13051160

18. Sauhats, A., Coban, H. H., Baltputnis, K., Broka, Z., Petrichenko, R., \& Varfolomejeva, R. (2016). Optimal investment and operational planning of a storage power plant. International Journal of Hydrogen Energy, 41 (29), 12443-12453. DOI: 10.1016/j.ijhydene.2016.03.078 